Review Article

\title{
Subclinical Hypothyroidism \& Infertility: A Review
}

\author{
HS Ferdous ${ }^{1}$, Faria Afsana ${ }^{1}$, Nazmul Kabir Qureshi², Rushda SB Rouf ${ }^{1}$, \\ Irfan N Noor ${ }^{3}$, AA Parvez ${ }^{1}$ and AS Mir ${ }^{1}$ \\ ${ }^{1}$ Department of Endocrinology, Bangladesh Institute of Research and Rehabilitation in Diabetes, Endocrine \\ and Metabolic Disorder (BIRDEM), Dhaka; ${ }^{2}$ Department of Medicine \& Endocrinology, United Hospital \\ Limited, Dhaka; ${ }^{3}$ Shundorpur Durgapur Union subcenter, Kaligonj, Jhenaidah
}

\begin{abstract}
Subclinical hypothyroidism (SCH) may be of greater clinical importance in women with "unexplained" infertility, especially when the luteal phase is inadequate, and such patients should be investigated for thyroid dysfunction in detail. To date, studies investigating the association between $\mathrm{SCH}$ and infertility are still based on the high serum thyroid stimulating hormone (TSH) levels while some older studies are based on the presence of an abnormal serum TSH after a thyrotropin releasing hormone (TRH) stimulation test. The recommendation in the current guidelines to treat subclinical hypothyroidism is based on minimal evidence and it is thought that with treatment the potential benefits outweigh the potential risks. Thyroxine-replacement therapy should be started in patients with $\mathrm{SCH}$ caused by conditions which are at high risk of progression to overt hypothyroidism.
\end{abstract}

Ibrahim Med. Coll. J. 2014; 8(1): 17-24

Keyword: Subclinical Hypothyroidism, Infertility, TSH, L-thyroxine

\section{Introduction}

Sub-fertility or infertility is a common condition having important psycho-social and economic impact. Prevalence of this condition is $12-14 \%$. Studies that estimated prevalence of sub-fertility included primary infertility (i.e., inability to conceive) and secondary infertility (i.e., inability to conceive again after one or more pregnancy). Nevertheless, many authors distinguish sub-fertility from infertility, the latter being the absolute inability to conceive due to absence of sperm, premature menopause, complete tubal obstruction etc. ${ }^{1-6}$ Thyroid dysfunction is a known contributing cause of infertility. Abnormal thyroid hormones affect normal menstrual pattern. Thyroid disorders is associated with an increased risk of miscarriage and possible long-term health consequences for the child. ${ }^{7}$ The impact of screening and treatment of subclinical thyroid disorders for infertility management has not extensively been documented in the literature. Hence, this review attempts to identify the impact of subclinical hypothyroidism on female infertility, and to propose guidelines for screening and treatment when indicated.

\section{Infertility}

Infertility is defined as inability to conceive after one year of regular normal sexual activity without any contraceptive measures. ${ }^{8}$ This definition was based on a study conducted on 5574 women during the period between 1946 and 1956 who had unprotected intercourse and ultimately conceived. Among these women $85 \%$ conceived within 12 months, $72 \%$ within first 6 months, and $50 \%$ within first 3 months. Two more recent prospective population-based studies showed that $50 \%$ of healthy women having unprotected intercourse become clinically pregnant during the first two cycles, and $80-90 \%$ during the first 6 months. ${ }^{9,10}$ Though these studies may not represent the general population

Address for Correspondence:

Dr. H.S.Ferdous, Senior Consultant, Department of Endocrinology, BIRDEM, 122 Kazi Nazrul Islam Avenue, Shahbag, Dhaka,Bangladesh.Email:dr_hsferdous@gmail.com 
globally, but these indicate that under appropriate circumstances, most females are likely to conceive early. ${ }^{11}$ The prevalence of infertility has been found stable over the recent decades. ${ }^{12}$

Causes of infertility among couples can be subdivided into four (4) broad categories: female infertility (35\%), male infertility (30\%), a combination of both $(20 \%)$, and unexplained or 'idiopathic' infertility $(15 \%) .{ }^{13,14}$

Causes of female infertility comprise endometriosis, tubal damage and ovulatory dysfunctions. Excepting tubal disorders which is more prevalent in Africa due to infections, all other causes of infertility have similar worldwide prevalence. ${ }^{15}$ Endometriosis is only considered as a cause of infertility when the disease exceeds stage I (as defined by the American Society for Reproductive Medicine). ${ }^{16}$ The cause of ovulatory dysfunction is further divided according to criteria established by World Health Organization (WHO) into: hypogonadotrophic - with low level of endogenous gonadotophins (Group -I), normogonadotrophic - with lnormal endogenous gonadotophins (Group -II) and hypergonadotrophic defective ovulation (Group -III). ${ }^{17}$ Age and smoking habit of woman also constitute important prognostic factors. ${ }^{18-21}$

Regarding male infertility, there are many factors which cannot be evaluated properly. Thus evaluation of sperm quality, its transport, and semen analysis remain of limited value as a predictor of fertilizing ability. ${ }^{22}$ The work-up of female infertility includes: a medical history, gynaecological examination, transvaginal ultrasonography, hormone profile, screening for infectious disease and, when indicated, hystero-salpingography and/or laparoscopy. ${ }^{23,24}$ In the presence of a normal spermogram and a normal female work-up, the cause of a couple's infertility is considered idiopathic.

\section{Sub clinical hypothyroidism (SCH)}

In a Consensus Development Conference held in September, 2002 the American Association of Clinical Endocrinologists(AACE), American Thyroid Association (ATA) and The Endocrine Society (TES) have defined $\mathrm{SCH}$ as a disorder with high serum thyroid-stimulating hormone (TSH) level above upper limit of the reference range with normal serum free thyroxine $\left(\mathrm{FT}_{4}\right)$ level. ${ }^{25}$ The third National Health and Nutrition Examination Survey (NHANES III) ${ }^{\mathbf{2 6}}$ screened 13,344 disease-free, euthyroid participants who were thyroid antibody negative. In this population, the median TSH concentration was $1.39 \mathrm{mIU} / \mathrm{L}[95 \%$ CI: 0.45-4.12 mIU/L]. This was accepted as normal by the above mentioned consensus conference on sub clinical thyroid diseases ${ }^{25}$ and Surks et al. ${ }^{27}$ agreed with this reference range. In contrast, the National Academy of Clinical Biochemistry ${ }^{28}$ suggested 0.4$2.5 \mathrm{mIU} / \mathrm{L}$ as the normal range, while Wartofsky and Dickey $^{29}$ and the AACE suggested $0.3-3.0 \mathrm{mIU} / \mathrm{L}$ as normal. ${ }^{30}$ According to United States Preventive Services Task Force (USPSTF) Guidelines defined SCH to have high serum TSH 2.5-10 mIU/L with a normal $\mathrm{FT}_{4}$ concentration.

As serum TSH varies over time in healthy people with occasional abnormal values, repeated serum TSH along with $\mathrm{FT}_{4}$ measurements within 3-4 months is required to confirm diagnosis of $\mathrm{SCH} .{ }^{31-33}$ If an elevated serum TSH concentration is confirmed with normal $\mathrm{FT}_{4}$, the diagnosis of $\mathrm{SCH}$ is made, and transient forms of $\mathrm{SCH}$ should be excluded. Normal serum free thyroxine concentrations may also be found among hospital in-patients with elevated serum TSH concentrations.

\section{Serum TSH during pregnancy}

Evidence based literatures strongly suggest that reference range for TSH is lower throughout pregnancy, both the lower and upper normal limit of serum TSH are decreased by about 0.1-0.2 $\mathrm{mIU} / \mathrm{L}$ and $1 \mathrm{mIU} / \mathrm{L}$ respectively, compared with the customary TSH reference interval of $0.4-4.0 \mathrm{mIU} / \mathrm{L}$ in non-pregnant women. The largest decrease in serum TSH is observed during the first trimester which is transient, apparently related to hCG levels. (Table 1)

The American Thyroid Association Taskforce on Thyroid Disease During Pregnancy and Postpartum recommends that if trimester-specific reference ranges for TSH are not available in the laboratory, the following reference ranges will be $0.1-2.5 \mathrm{mIU} / \mathrm{L}$ in first trimester, $0.2-3.0 \mathrm{mIU} / \mathrm{L}$ in second trimester, and $0.3-3.0 \mathrm{mIU} / \mathrm{L}$ in third trimester.

Sub clinical hypothyroidism ( $\mathrm{SCH}$ ) has recently been challenged. Variations of $\mathrm{FT}_{4}$ within the reference range in individual is less than that observed in a population. These data might reflect an abnormally low $\mathrm{FT}_{4}$ value for patients who present with a mildly 
Table-1: Trimester-Specific Serum TSH Reference Intervals

\begin{tabular}{l|ccc}
\hline \multirow{2}{*}{ References } & \multicolumn{3}{|c}{ Serum TSH mIU/L [median (percentiles) } \\
\cline { 2 - 4 } & First Trimester & Second trimester & Third trimester \\
\hline Haddow et al. $(2004)^{34}$ & $0.94(0.08-2.73)$ & $1.29(0.39-2.70)$ & - \\
Stricker et al. $(2007)^{35}$ & $1.04(0.09-2.83)$ & $1.02(0.20-2.79)$ & $1.14(0.31-2.90)$ \\
Panesar et al. $(2001)^{36}$ & $0.80(0.03-2.30)$ & $1.10(0.03-3.10)$ & $1.30(0.13-3.50)$ \\
Soldin et al. $(2007)^{37}$ & $0.98(0.24-2.99)$ & $1.09(0.46-2.95)$ & $1.20(0.43-2.78)$ \\
Bocos-Terraz et al. $(2009)^{38}$ & $0.92(0.03-2.65)$ & $1.12(0.12-2.64)$ & $1.29(0.23-3.56)$ \\
Marwaha et al. (2008) & $2.10(0.60-5.00)$ & $2.40(0.43-5.78)$ & $2.10(0.74-5.70)$ \\
\hline
\end{tabular}

NB: Median TSH in mIU/L, with data indicating 5th and 95 th percentiles s $^{34,36,39}$ or 2.5 th and 97.5 th $_{\text {percentiles }}{ }^{35,37,38}$.

increased serum TSH. ${ }^{40,41}$ Many authors have proposed serum TSH $2.5 \mathrm{mIU} / \mathrm{L}$ as upper normal limit. However, there is no general agreement among the endocrinologists about the most appropriate normal (i.e. physiologically relevant) upper limit serum TSH. ${ }^{42}$

\section{Sub clinical hypothyroidism (SCH) and infertility}

Studies investigating the association between $\mathrm{SCH}$ and infertility are still based on the high serum TSH levels and some older studies are based on the presence of an abnormal serum TSH after a TRH stimulation test. Table 2 summarizes the most relevant studies on the prevalence of $\mathrm{SCH}$ in women with infertility. In the study by Bohnet et al., SCH was considered as an infertility factor by itself because treatment with L-thyroxine $50 \mathrm{ìg} /$ day had normalized their mid progesterone secretion and two among the eleven treated women became pregnant. ${ }^{43}$ Bals-Pratsch et al. did not observe corpus luteum insufficiency in infertile women with $\mathrm{SCH} .{ }^{44} \mathrm{Gerhard}$ et al. reported a positive correlation between basal TSH, LH and testosterone concentrations in the early follicular phase. Women with an elevated serum TSH had a lower pregnancy rate than the women with a normal TRH stimulated serum TSH. Eighty out of 185 infertile women had an abnormal TRH test, but only one woman had an increased basal serum TSH $(0.5 \%) .{ }^{45}$ In the study by Shalev et al., the prevalence of SCH was $0.67 \%$ in 444 infertile women, all with ovulatory dysfunction. ${ }^{46}$ Grassi et al. investigated 129 women of infertile couples with ovulatory dysfunction, idiopathic and male infertility. ${ }^{47}$ Six patients $(4 \cdot 6 \%)$ had a basal serum TSH level $>4.5 \mathrm{mU} / \mathrm{L}$ and five of these six women had Autoimmune Thyroid Disease (AITD). The authors noted that the mean duration of infertility was significantly longer in the patients having thyroid disorders like abnormal TSH and/or AITD compared to those without any abnormality ( $3 \cdot 8$ vs. $2 \cdot 6$ years; $\mathrm{P}=0 \cdot 005)$. In a case control study, Poppe et al investigated the prevalence of SCH (serum TSH $>4 \cdot 2 \mathrm{mU} / \mathrm{l})$ in women of infertile couples $(\mathrm{n}=438)$ who came for the first time to the centre of reproductive medicine. The control population consisted of 100 age-matched fertile women. The prevalence of a high serum TSH was comparable in both the study group and controls $(<1 \% ; \mathrm{P}=\mathrm{ns}) .^{48}$ Overall, the studies investigating the association between SCH and infertility were poorly controlled. Considering the largest cohorts published, the prevalence of $\mathrm{SCH}$ in infertile women ranged from $1 \%$ to $4 \%$ and most cases with $\mathrm{SCH}$ were associated with ovulatory dysfunction.

Recently, Raber et al. Investigated prospectively a group of 283 women with infertility. ${ }^{49}$ All patients underwent a TRH stimulation test ( $\mathrm{SCH}$ was defined as a serum TSH $>15 \mathrm{mU} / \mathrm{L}$ ). Women with a diagnosis of SCH were treated with thyroxine and followed prospectively over a 5 -year period. Among these women $34 \%$ had SCH, an unusually high prevalence reflecting the specific referral pattern. Among the women who became pregnant during the follow-up period, over $25 \%$ still had SCH. Furthermore, the women who never achieved a basal serum TSH $<2.5 \mathrm{mU} / \mathrm{L}$ or a TRHstimulated TSH $<20 \mathrm{mU} / \mathrm{L}$ became pregnant less frequently than those who could achieve. More frequent abortions were also observed in the women with a higher basal serum TSH (independent of the presence of autoimmunity). Arojoki et al found elevated serum TSH levels ( $>5.5 \mathrm{mU} / \mathrm{L}$ ) in $4 \%$ women presenting with infertility for the first time..$^{50}$ The prevalence of 
having an increased serum TSH was highest in the group with ovulatory dysfunction $(6 \cdot 3 \%)$. Prior to infertility examinations, 10 of 299 women were already receiving $\mathrm{L}$-thyroxine for primary hypothyroidism. The incidental finding of an elevated serum TSH value in patients with infertility was therefore reduced to four among 299 women $(1 \cdot 3 \%)$, and this was in the range of the prevalence of $\mathrm{SCH}$ in the general population in Finland (2-3\%).

In the studies summarized in Table 2, three included a control (fertile population) and the prevalence of $\mathrm{SCH}$ was comparable between the study group and controls.

The prevalence of SCH was considerably higher in the studies based on a TRH stimulation test to detect SCH compared with the studies that were based only on the upper limit of basal serum TSH. This difference might indicate that in older studies, using less sensitive measurements of serum TSH, the actual TSH reference levels are perhaps slightly higher in the setting of infertility. In a study, basal and TRH-stimulated TSH concentrations were measured in 834 infertile women, and $20 \%$ had abnormal results. ${ }^{51}$ Postcoital tests and spontaneous conceptions were significantly poorer in women with $\mathrm{SCH}$ than in controls. Staub et al. ${ }^{\mathbf{5 2}}$ suggested that secondary hyperprolactinemia could be a cause of infertility in $\mathrm{SCH}$ women. In contrast, menstrual function in $\mathrm{SCH}$ patients and controls was similar, such as luteinizing hormone pulse patterns, 24-h mean serum luteinizing hormone, TSH, and prolactin concentrations. ${ }^{53}$ Lincoln et al. reported a $2.3 \%$ prevalence of elevated serum
TSH concentrations in 704 women with infertility for at least 1 year. Eleven out of sixteen hypothyroid patients' had ovulatory dysfunction. TSH values were not determined in the control group. ${ }^{54}$

\section{Treatment interventions and guideline for subclinical/clinical hypothyroidism}

Some studies used levothyroxine as treatment. Five studies reported the effect of treatment interventions for clinical and/or subclinical hypothyroidism. A randomized non-placebo controlled trial reported that after treatment with L-thyroxine subclinical hypothyroid women undergoing IVF/ICSI had a significantly higher embryo implantation rate (RR: $1.8,1.00-3.25 ; \mathrm{P} 1 / 40.05)$ and live birth rate (RR: $2.13,1.07-4.21 ; \mathrm{P} 1 / 40.03)$ compared to untreated women. ${ }^{55}$ No significant differences were found for clinical pregnancy (RR: $1.42,0.81-2.45 ; \mathrm{P} 1 / 40.22$ ) or miscarriage rate (RR: 0.8, 0.00-1.36; P 1/4 0.08).

Two cohort studies reported on pregnancy complications for women with clinical or sub clinical hypothyroidism who were adequately, and who were not adequately treated. ${ }^{\mathbf{5 6 , 5 7}}$ Not adequately treated hypothyroid women had higher TSH and a lower than normal thyroxine level, despite treatment. In the case of subclinical hypothyroidism, a TSH higher than the reference interval despite treatment was defined as not adequately treated. The first study showed no significant difference in the prevalence of gestational hypertension in 68 women not adequately treated for subclinical or clinical

Table-2: Prevalence of subclinical hypothyroidism in infertile women

\begin{tabular}{|c|c|c|c|c|}
\hline Reference & $\begin{array}{c}\text { Prevalence of } \\
\text { SCH in patients }\end{array}$ & $\begin{array}{l}\text { Prevalence of } \\
\text { SCH in controls }\end{array}$ & $\begin{array}{c}\text { SCH } \\
\text { defined by }\end{array}$ & $\begin{array}{c}\text { Type } \\
\text { of study }\end{array}$ \\
\hline Bohnet et al. $(1981)^{43}$ & $11 \%(20 / 185)$ & No controls & $\begin{array}{c}\text { Basal TSH }>3 \mathrm{mU} / 1 \text { or } \\
\text { peak } \mathrm{TSH} \ddagger>15 \mathrm{mU} / 1\end{array}$ & $\mathrm{P}$ \\
\hline Gerhard et al. (1991) ${ }^{45}$ & $43 \% *(80 / 185)$ & No controls & Peak TSH $\ddagger>20 \mathrm{mU} / 1$ & $\mathrm{P}$ \\
\hline Shalev et al. $(1994)^{46}$ & $0 \cdot 7 \%(3 / 444)$ & No controls & Basal TSH $>4.5 \mathrm{mU} / 1$ & $\mathrm{R}$ \\
\hline Grassi et al. $(2001)^{47}$ & $4 \cdot 6 \%(6 / 129)$ & Controls & Basal TSH > $4.5 \mathrm{mU} / 1$ & $\mathrm{P}$ \\
\hline Poppe et al. $(2002)^{48}$ & $0 \cdot 9 \%(4 / 438)$ & $<1 \%$ & Basal TSH $>4 \cdot 2 \mathrm{mU} / 1$ & $\mathrm{P}$ \\
\hline Raber et al. $(2003)^{49}$ & $34 \%(96 / 283)$ & No controls & $\begin{array}{c}\text { Basal TSH }>4 \mathrm{mU} / 1 \text { or } \\
\text { peak TSH } \ddagger>15 \mathrm{mU} / 1\end{array}$ & $\mathrm{P}$ \\
\hline Arojoki et al. $(2000)^{\mathbf{5 0}}$ & $1 \cdot 3 \%(4 / 299)$ & $2-3 \% \dagger$ & Basal TSH $>5.5 \mathrm{mU} / 1$ & $\mathrm{R}$ \\
\hline
\end{tabular}

SCH: sub clinical hypothyroidism; $P$ : prospective; $R$ : retrospective. *One in 185 patients had a basal serum TSH $>6$ mU/L (0.5\%). †Prevalence in the Finnish population. $\ddagger$ Peak serum TSH after TRH-stimulation test. 
hypothyroidism compared with 38 women who remain still hypothyroid despite treatment (RR: 0.14, CI: 0.012.20: $\mathrm{P} 1 / 40.16$ ) for clinical hypothyroidism, (RR: 0.41 , CI:0.11-1.62: $\mathrm{P}^{1 / 40.21}$ ) for subclinical hypothyroidism. ${ }^{56}$ The second study reported no significant difference in Neonatal Intensive Care Unit (NICU) admissions (RR:0.31, CI:0.08-1.2: P1/40.09). A significant difference was found in low birth weight (RR:0.31, CI: 0.11-0.92: $\mathrm{P} 1 \frac{1}{4}$ 0.04) for 127 women with subclinical hypothyroidism with normal TSH level with levothyroxine treatment compared with 40 women with abnormal TSH levels in the first trimester despite levothyroxine treatment, while Caesarean section rates were almost similar in the two groups, respectively $27.5 \%$ and $29.1 \%{ }^{57}$ One case control study on 38 women with hypothyroidism treated with levothyroxine during pregnancy reported no significant difference in the IQ level, verbal performance or cognitive performance between the 19 children of subclinically hypothyroid mothers despite treatment and 19 children of mothers who were euthyroid with treatment. ${ }^{58}$

European Society of Clinical Pharmacy (ESCP) guideline recommends levothyroxine replacement in women with subclinical hypothyroidism, given the fact that the potential benefits outweigh the potential risks. For obstetrical outcome, United States Preventive Services Task Force (USPSTF) recommendation level is B, evidence is fair (Grade 1). For neurological outcome, USPSTF recommendation level is I, evidence is poor (Grade: 0). The European Society of Human Reproduction and Embryology (ESHRE) and the Royal College of Obstretians ans Gynaecologists (RCOG) do not employ guidelines on sub clinical hypothyroidism in pregnancy. Only one among the seven studies on hypothyroidism reported separate data on subclinical hypothyroidism. This study showed that gestational hypertension was more commonly found in not adequately treated women than in adequately treated women, though the difference was not significant. The recommendation in the current guidelines to treat subclinical hypothyroidism is based on minimal evidence. It is thought that with treatmant the potential benefits outweigh the potential risks. L-Thyroxine replacement therapy should be started in patients with SCH caused by conditions which are at high risk of progression to overt hypothyroidism. The main controversy revolves around the upper limits of the serum TSH concentration beyond which therapy should be started. Patients with $\mathrm{SCH}$ should always be given thyroid-replacement therapy when serum TSH concentrations are persistently above $10 \mathrm{mIU} / \mathrm{L}$. In $\mathrm{SCH}$ patients presenting with persistently elevated serum TSH concentrations less than $10 \mathrm{mIU} / 1$, L-thyroxine replacement therapy should be started in presence of at least one of the following conditions: pregnancy, childhood, elevated anti-thyroid autoantibody, evidence of hypo-echoic thyroid gland on ultrasound, women with persistent infertility, diffuse or nodular goitre, or symptoms of hypothyroidism. In patients with a serum TSH above normal but below $10 \mathrm{mIU} / \mathrm{L}$ and who do not have any of these conditions, L-thyroxine therapy remains controversial. ${ }^{59-61}$

\section{Conclusion}

Severe hypothyroidism is commonly associated with failure of ovulation. Ovulation followed by pregnancy can occur in case of mild hypothyroidism. However, these pregnancies are often associated with abortions, stillbirths, or pre-maturity. Subclinical hypothyroidism may be of greater clinical importance in women with "unexplained" infertility, especially when the luteal phase is inadequate, and such patients should be investigated in depth for thyroid dysfunction. Treatment with levothyroxineis is recommended for women with clinical hypothyroidism because it lowers the risk for miscarriage and preterm delivery. Our review shows that for subclinical hypothyroidism there is insufficient evidence to recommend for or against the universal treatment with levothyroxine. But in case of infertility it is always a preferable option to start levothyroxine as it not only enhance the fertility but also ensures euthyroid state which is very important to continue the pregnancy till delivery.

\section{References}

1. Downey J, Yingling S, McKinney M, et al. Mood disorders, psychiatric symptoms, and distress in women presenting for infertility evaluation. Fertility \& Sterility 1989; 52: 425-432.

2. Healy DL, Trounson AO, Andersen AN, et al. Female infertility: causes and treatment. Lancet 1994; 343: 1539-1544.

3. Whiteford LM \& Gonzalez L. Stigma: the hidden burden of infertility. Social Science and Medicine 1995; 40: 27-36.

4. Hoxsey R, Rinehart JS. Infertility and subsequent pregnancy. Clinics in Perinatology 1997; 4: 321-342. 
5. Hull MG, Glazener CM, Kelly NJ, et al. Population study of causes, treatment, and outcome of infertility. British Medical Journal 1985; 14: 1693-1697.

6. Mosher WD, Pratt WF. Fecundity and infertility in the United States: incidence and trends. Fertility \& Sterility 1991; 52: 192-193.

7. Krassas GE. Thyroid disease and female reproduction. Fertility \& Sterility 2000; 74: 1063-1070.

8. Evers JL. Female subfertility. Lancet 2002; 360: 151-159.

9. Wang X, Chen C, Wang L, Chen D, Guang W, French J. Conception, early pregnancy loss, and time to clinical pregnancy: a population-based prospective study. Fertility and Sterility 2003; 79: 577-584.

10. Gnoth C, Godehardt D, Godehardt E, Frank-Herrmann $P$, Freundl G. Time to pregnancy: results of the German prospective study and impact on the management of infertility. Human Reproduction 2003;18:1959-1966.

11. Brosens I, Gordts S, Valkenburg M, Puttemans P, Campo R, Gordts S. Investigation of the infertile couple: when is the appropriate time to explore female infertility? Human Reproduction 2004; 19: 1689-1692.

12. Mosher WD, Pratt WF. Fecundity and infertility in the United States: incidence and trends. Fertility and Sterility 1991; 56: 192-193.

13. Thonneau P, Marchand S, Tallec A, Ferial ML, Ducot B, Lansac J, Lopes P, Tabaste JM, Spira A. Incidence and main causes of infertility in a resident population (1 850 000) of three French regions. Human Reproduction 1991;6:811-816.

14. Healy DL, Trounson AO, Andersen AN. Female infertility: causes and treatment. Lancet 1994; 343: $1539-1544$.

15. Cates W, Farley TM, Rowe PJ. Worldwide patterns of infertility: is Africa different? Lancet 1985; 2: 596598.

16. Schenken RS, Guzick DS. Revised endometriosis classification: 1996. Fertility and Sterility 1997; 67: 815-816.

17. Lunenfeld B, Insler V. Classification of amenorrhoeic states and their treatment by ovulation induction. Clinical Endocrinology 1974; 3: 223-237.

18. Augood C, Duckitt K, Templeton AA. Smoking and female infertility: a systematic review and meta-analysis. Human Reproduction 1998; 13: 1532-1539.

19. Dunson DB, Colombo B, Baird DD. Changes with age in the level and duration of fertility in the menstrual cycle. Human Reproduction 2002; 17: 1399-1403.

20. Delhanty JD. Pre-implantation genetics: an explanation for poor human fertility? Annals of Human Genetics 2001; 65: 331-338.
21. Achermann JC, Ozisik G, Meeks JJ, Jameson JL. Genetic causes of human reproductive disease. Journal of Clinical Endocrinology and Metabolism 2002; 87: 2447-2454.

22. ESHRE Capri Workshop Group. Diagnosis and management of the infertile couple: missing information. Human Reproduction 2004; 10: 295-307.

23. Cahill DJ, Wardle PG. Management of infertility. BMJ 2002; 325: 28-32.

24. Rosene-Montella K, Keely E, Laifer SA, Lee RV. Evaluation and management of infertility in women: the internists' role. Annals of Internal Medicine 2000; 132: 973-981.

25. Surks MI, Ortiz E, Daniels GH, et al. Subclinical thyroid disease. Scientific review and guidelines for diagnosis and management. JAMA 2004; 291: 228238.

26. Hollowell JG, Staehling NW, Flanders WD, et al. Serum TSH, T(4), and thyroid antibodies in the United States population (1988 to 1994): National Health and Nutrition Examination Survey (NHANES III). J Clin Endocrinol Metab 2002; 87: 489-499.

27. Surks MI, Goswami G, Daniels GH. The thyrotropin reference range should remain unchanged. $J$ Clin Endocrinol Metab 2005; 90: 5489-5496.

28. Baloch Z, Carayon $\mathrm{P}$, Conte-Delvox $\mathrm{B}$, et al. Guidelines Committee, National Academy of Clinical Biochemistry. Laboratory medicine practice guidelines. Laboratory support for the diagnosis and monitoring of thyroid disease. Thyroid 2003; 13: 3-126.

29. Wartofsky L, Dickey RA. The evidence for a narrower thyrotropin reference range is compelling. J Clin Endocrinol Metab 2005; 90: 5483-5488.

30. American Association of Clinical Endocrinologists. American Association of Clinical Endocrinologists medical guidelines for clinical practice for the evaluation and treatment of hyperthyroidism and hypothyroidism. Endocr Pract 2002; 8: 457-469.

31. Feldt-Rasmussen U, Petersen PH, Blaabjerg O, Horder M. Long-term variability in serum thyroglobulin and thyroid related hormones in healthy subjects. Acta Endocrinol (Copenh) 1980; 95: 328-334.

32. Maes M, Mommen K, Hendrickx D, et al. Components of biological variation, including seasonality in blood concentrations of TSH, TT4, FT4, PRL, cortisol and testosterone in healthy volunteers. Clin Endocrinol (Oxf) 1997; 46: 587-598.

33. Andersen S, Brunn NH, Pedersen KM, Laurberg P. Biologic variation is important for interpretation of thyroid function tests. Thyroid 2003; 13: 10691078 . 
34. Haddow JE, Knight GJ, Palomaki GE, McClain MR, Pulkkinen AJ. The reference range and within-person variability of thyroid stimulating hormone during the first and second trimesters of pregnancy. J Med Screen 2004; 11: 170-174.

35. Stricker R, Echenard M, Eberhart R, Chevailler MC, Perez V, Quinn FA, Stricker R. Evaluation of maternal thyroid function during pregnancy: the importance of using gestational age-specific reference intervals. Eur J Endocrinol 2007; 157: 509-514.

36. Panesar NS, Li CY, Rogers MS. Reference intervals for thyroid hormones in pregnant Chinese women. Ann Clin Biochem 2001; 38: 329-332.

37. Soldin OP, Soldin D, Sastoque M. Gestation-specific thyroxine and thyroid stimulating hormone levels in the United States and worldwide. Ther Drug Monit 2007; 29: 553-559.

38. Bocos-Terraz JP, Izquierdo-Alvarez S, Bancalero-Flores JL, Alvarez-Lahuerta R, Aznar-Sauca A, Real-Lopez E, Ibanez-Marco R, Bocanegra-Garcia V, Rivera-Sanchez G. Thyroid hormones according to gestational age in pregnant Spanish women. BMC Res Notes 2009; 2: 237.

39. Marwaha RK, Chopra S, Gopalakrishnan S, Sharma B, Kanwar RS, Sastry A, Singh S. Establishment of reference range for thyroid hormones in normal pregnant Indian women. BJOG 2008; 115: 602-606.

40. Andersen S, Pedersen KM, Bruun NH, Laurberg P. Narrow individual variations in serum $\mathrm{T}(4)$ and $\mathrm{T}(3)$ in normal subjects: a clue to the understanding of subclinical thyroid disease. Journal of Clinical Endocrinology and Metabolism 2002; 87: 1068-1072.

41. Baloch Z, Carayon P, Conte-Devolx B, Demers LM, Feldt-Rasmussen U, Henry JF, et al. Laboratory medicine practice guidelines. Laboratory support for the diagnosis and monitoring of thyroid disease. Thyroid 2003; 13: 3-126.

42. Brabant G, Beck-Peccoz P, Jarzab B, Laurberg P, OrgiazziJ,Szabolcs I, Weetman AP, Wiersinga WM. Is there a need to re-define the upper normal limit of TSH? European Journal of Endocrinology 2006; 154: 633-637.

43. Bohnet HG, Fiedler K, Leidenberger FA. Subclinical hypothyroidism and infertility. Lancet 1981; 5: 1278.

44. Bals-Pratsch M, De Geyter C, Muller T, Frieling U, Lerchl A, Pirke KM, et al. Episodic variations of prolactin, thyroid-stimulating hormone, luteinizing hormone, melatonin and cortisol in infertile women with subclinical hypothyroidism. Human Reproduction 1997; 12: 896-904.

45. Gerhard I, Becker T, Eggert-Kruse W, Klinga K, Runnebaum B. Thyroid and ovarian function in infertile women. Human Reproduction 1991; 6: 338-345.
46. Shalev, E., Eliyahu, S., Ziv, M. \& Ben-Ami, M. Routine thyroid function tests in infertile women: are they necessary? American Journal of Obstetrics and Gynecology 1994; 171: 1191-1192.

47. Grassi G, Balsamo A, Ansaldi C, Balbo A, Massobrio M, Benedetto C. Thyroid autoimmunity and infertility. Gynecological Endocrinology 2001; 15: 389-396.

48. Poppe K, Glinoer D, Van Steirteghem A, Tournaye H, Devroey P, Schiettecatte J, Velkeniers B. Thyroid dysfunction and autoimmunity in infertile women. Thyroid 2002; 12: 997-1001.

49. Raber W, Nowotny P, Vytiska-Binstorfer E, Vierhapper $\mathrm{H}$. Thyroxine treatment modified in infertile women according to thyroxine-releasing hormone testing: 5year follow-up of 283women referred after exclusion of absolute causes of infertility. Human Reproduction 2003; 18: 707-714.

50. Arojoki M, Jokimaa V, Juuti A, Koskinen P, Irjala K, Anttila L. Hypothyroidism among infertile women in Finland. Gynecological Endocrinology 2000; 14: 127-131.

51. Gerhard I, Eggert-Kruse W, Merzoug K, et al. Thyrotropin-releasing hormone (TRH) and metoclopramide testing in infertile women. Gynecol Endocrinol 1991; 5: 15-32.

52. Staub JJ, Althaus BU, Engler H, et al. Spectrum of subclinical and overt hypothyroidism: effect on thyrotropin, prolactin, and thyroid reserve and metabolic impact on peripheral target tissues. Am J Med 1992; 92: 631-642.

53. Bals-Pratsch M, De Geyter C, Muller T, et al. Episodic variations of prolactin, thyroid stimulating hormone, luteinizing hormone, melatonin and cortisol in infertile women with subclinical hypothyroidism. Hum Reprod 1997; 12: 896-904.

54. Lincoln SR, Ke RW, Kutteh WH. Screening for hypothyroidism in infertile women. J Reprod Med 1999; 44: 455-457.

55. Kim CH, Ahn JW, Kang SP, Kim SH, Chae HD, Kang BM. Effect of levothyroxine treatment on in vitro fertilization and pregnancy outcome in infertile women with subclinical hypothyroidism undergoing in vitro fertilization/ intracytoplasmic sperm injection. Fertil Steril 2011; 95: 1650-1654.

56. Leung AS, Millar LK, Koonings PP, Montoro M, Mestman JH. Perinatal outcome in hypothyroid pregnancies. ObstetGynecol 1993; 81: 349-353.

57. Idris I, Srinivasan R, Simm A, Page RC. Maternal hypothyroidism in early and late gestation: effects on neonatal and obstetric outcome. Clin Endocrinol (Oxf) 2005; 63: 560-565. 
58. Behrooz HG, Tohidi M, Mehrabi Y, Behrooz EG, Tehranidoost M, Azizi F. Subclinical hypothyroidism in pregnancy: intellectual development of offspring. Thyroid 2011; 21: 1143-1147.

59. Papi G, Uberti ED, Betterle C, Carani C, Pearce EN, Lewis E, Braverman LE, Elio Roti E. Subclinical hypothyroidism. Curr Opin Endocrinol Diabetes Obes 2007; 14: 197-208.
60. Krassas GE, Thyroid disease and female reproduction. Fertility and Sterility 2000; 74: 1063-1070.

61. Vissenberg R, Boogaard E, Wely M, Post J, Fliers E, Bisschop P, Goddijn M. Treatment of thyroid disorders before conception and in early pregnancy: a systematic review. Human Reproduction. Update 2012; 18(4): 360-373. 